\title{
MINAT MASYARAKAT PERUMAHAN NUSA INDAH PERMAI TEMBILAHAN BARAT DALAM MENYALURKAN ZAKAT MAL KE BADAN AMIL ZAKAT NASIONAL KABUPATEN INDRAGIRI HILIR
}

\author{
Seri Yanti Siagian ${ }^{1}$
}

\begin{abstract}
Abstrak
Penelitian ini dilaksanakan di Perumahan Nusa Indah Permai Tembilahan Barat, bertujuan untuk mengetahui bagaimana Minat Masyarakat Dalam Menyalurkan Zakat Mal Ke Badan Amil Zakat Nasional Kabupaten Indragiri Hilir.Populasi penelitian adalah Masyarakat Perumahan Nusa Indah Permai Tembilahan Baratyang berjumlah 226 orang, kemudian diambil sampel dari kelas menengah atas yang memiliki pekerjaan tetap dan penghasilan tiap bulan serta haul dan nisab zakatnya terpenuhi yang berjumlah 134 orang. Penelitian ini adalah Minat Masyarakat Dalam Menyalurkan Zakat Mal Ke Badan Amil Zakat Nasional Kabupaten Indragiri Hilir (X). Teknik pengambilan data yang digunakan adalah dengan menggunakan angket, wawancara dan dokumentasi. Sedangkan data dianalisa dengan teknik deskriptif kuanitatif dengan persentase. Hasil penelitian menunjukkan bahwa Minat Masyakat Perumahan Nusa Indah Permai Tembilahan Barat Dalam Menyalurkan Zakat Mal Ke Badan Amil Zakat Nasional Kabupaten Indragiri Hilir menunjukkan bahwasanya mereka "Kurang Memiliki Minat", terlihat dari hasil Questioner yang disebarkan dengan persentasenya 28,72\%
\end{abstract}

Kata kunci: Minat Masyarat, Menyalurkan Zakat Mal.

\footnotetext{
${ }^{1}$ Dosen Tetap Ekonomi Syariah STAI Auliurrasyidin Tembilahan
} 


\section{A. Pendahuluan}

Masyarakat yang berada dalam kategori wajib dalam mengeluarkan zakat mal adalah masyarakat yang kebutuhan sehari-harinya tercukupi kemudian berlebih dari segi materinya serta haul dan nisabnya sudah sampai. Kategori masyarakat yang wajib mengeluarkan zakat mal ada di lingkungan Perumahan Nusa Indah Permai Tembilahan Barat karena mayoritas masyarakat yang berada di Perumahan Nusa Indah Permai Tembilahan Barat berada pada golongan menengah keatas, sehingga masyarakatnya wajib mengeluarkan zakat mal setiap tahunnya.

Masyarakat di Perumahan Nusa Indah Permai Tembilahan Barat secara keseluruhan mengeluarkan zakat mal setiap tahunnya sesuai dengan anjuran syari'at islam. Namun banyak ditemukan dalam penyaluran zakat malnya dilakukan secara pribadi kepada orang yang membutuhkan. Padahal seharusnya masyarakat memberikan kepercayaan atau memberikan hak kepada Badan Amil Zakat yang menjadi lembaga atau tempat penerima dan penyalur zakat mal ke orang yang membutuhkan.

Sesuai dengan ketentuannya Badan Amil Zakat adalah lembaga atau tempat penerima zakat dan penyalur zakat yang tepat. Dalam kegiatan menyalurkan zakat mal ke Badan Amil Zakat Nasional (BAZNAS) masyarakat harus memiliki minat agar penyaluran zakat dapat berjalan dengan baik dan hasilnya optimal.

Tujuan penelitian ini adalah untuk mengetahui dengan jelas minat masyarakat Perumahan Nusa Indah Permai Tembilahan Barat dalam menyalurkan zakat mal ke Badan Amil Zakat Nasional (BAZNAS) Kabupaten Indragiri Hilir dan Untuk mengetahui dengan jelas faktor-farktor yang mempengaruhi Minat Masyarakat Perumahan Nusa Indah Permai Tembilahan Barat dalam Menyalurkan Zakat Mal ke Badan Amil Zakat Nasional (BAZNAS) Kabupaten Indragiri Hilir. 


\section{B. Metode}

Penelitian ini dilaksanakan di Perumahan Nusa Indah Permai Tembilahan Barat Kabupaten Indragiri Hilir Provinsi Riau. Jenis penelitian yang dilakukan adalah penelitian deskriptif kuantitatif dengan mengumpulkan data menggunakan instrument angket dan wawancara. Penelitian deskriptif ini bertujuan untuk memecahkan masalah aktual yang dihadapi serta mengumpulkan data atau informasi untuk disusun, dijelaskan dan dianalisis.

\section{Hasil dan Pembahasan}

\section{Minat}

Minat pada dasarnya merupakan suatu perangkat mental yang terdiri dari suatu campuran dari perasaan, harapan, pendirian, prasangka, rasa takut atau kecendrungan lain yang mengarahkan individu kepada suatu pilihan tertentu. ${ }^{2}$ Sedangkan minat menurut Slameto adalah kecendrungan yang tetap untuk memperhatikan dan mengenang beberapa kegiatan. Kegiatan yang diminati seseorang, diperhatikan terus menerus yang disertai dengan rasa senang. Jadi berbeda dengan perhatian, karena perhatian sifatnya sementara (tidak dalam waktu yang lama) dan belum tentu diikuti dengan perasaan senang, sedangkan minat selalu diikuti dengan perasaan senang dari situ diperoleh kepuasan. ${ }^{3}$

Minat sangat bersifat pribadi, orang lain tidak bisa menumbuhkannya dalam diri seseorang, tidak dapat memelihara dan mengembangkan minat itu serta tidak mungkin berminat terhadap sesuatu hal sebagai wakil dari masing-masing orang. Oleh karena itu minat

\footnotetext{
${ }^{2}$ Andi Mapare, Psikologi Remaja, (Surabaya: Usaha Nasional, 2003), hlm.62

3 Slameto, Belajar dan Faktor-faktor yang Mempengaruhi, (Jakarta: Rineka Cipta, 2003), hlm. 57
}

66 
merupakan suatu sikap batin dalam diri seseorang maka tumbuh nya minat itu bermuara pada berbagai dorongan batin (motives). Berbagai motif harus digerakkan sehingga dapat menjadi sebuah motivasi yang kuat untuk mencapai sesuatu. ${ }^{4}$ Seseorang yang dapat menciptakan sendiri sebagai dorongan batin sudah berada pada jalur yang tepat untuk memperkembangkan minatnya dimasyarakat atau dilingkungan masyarakatnya.

Minat secara umum dapat diartikan sebagai rasa lebih suka dan rasa ketertarikan pada suatu hal atau aktivitas, tanpa ada yang menyuruh. ${ }^{5}$ Minat juga pada dasarnya adalah penerimaan akan suatu hubungan antara diri sendiri dengan sesuetu diluar diri. Semakin kuat atau dekat hubungan tersebut, semakin besar minat. ${ }^{6}$

Crow and crow mengatakan bahwa minat berhubungan dengan gaya gerak yang mendorong seseorang untuk mengahadapi atau berurusan dengan orang, benda, kegiatan, pengalaman yang dirangsang oleh kegiatan itu sendiri. ${ }^{7}$ Jadi minat tidak hanya di ekspresikan melalalui pernyataan yang menunjukan bahwa masyarakat lebih menyukai sesuatu dari pada yang lainnya, tetapi dapat juga di implementasikan melalui partisipasi aktif dalam suatu kegiatan. Masyarakat yang berminat terhadap sesuatu cendrung untuk memberikan perhatian yang lebih besar terhadap sesuatu yang diminati itu dan sama sekali tak menghiraukan sesuatu yang lain.

Dari pernyataan diatas dapat disimpulkan bahwa seseorang yang berminat terhadap suatu aktivitas akan memperhatikan aktivitas itu secara konsisten dengan rasa senang dikarenakan hal tersebut datang dari dalam

4 Ngalim Purwanto, Psikologi Pendidikan, ( Bandung: PT Remaja Rosdakarya, 2014), hlm. 71

5 Slameto, Belajar dan Faktor-faktor yang Mempengaruhi, (Jakarta: Rineka Cipta, 2003), hlm. 180

6 Ibid, hlm. 180

7 H. Djaali, Psikologi Pendidikan, (Jakarta: Bumi Aksara, 2009), hlm. 121 
diri seseorang yang didasarkan rasa suka dan tidak adanya paksaan dari pihak luar. Dengan kata lain, minat adalah suatu rasa lebih suka dan rasa keterikatan pada suatu hal atau aktivitas, tanpa ada yang memaksa. Menurut Jacob W. Getels, Seseorang yang berminat terhadap sesuatu yang diminati itu sama sekali tidak akan menghiraukan sesuatu yang lain. ${ }^{8}$ Dengan demikian minat dapat diartikan sebagai kecenderungan sifat yang terorganisir berdasarkan dari pengalaman seseorang, yang mendorong seseorang atau individu untuk mencari keterangan atau fakta-fakta dari sebuah objek, aktivitas atau kegiatan, pemahaman, skill, tujuan perhatian atau murni ingin mahir dalam hal tertentu.

Minat merupakan sesuatu yang abstrak, oleh karena itu untuk melihat indikatornya hanya bisa melalui gejala yang ditunjukan oleh individu dalam perbuatannya. Secara umum, minat dapat dibagi menjadi dua macam yakni:

1) Minat yang Diekspresikan

2) Seseorang dapat mengungkapkan minatnya dengan kata-kata tertentu misalnya tertarik pada kegiatan menyalurkan zakat mal, maka ia akan berbagi, meraskan kesulitan orang-orang yang tidak mampu disekitarnya.

3) Minat yang Diwujudkan

Seseorang dapat mewujudkan melalui tindakan atau perbuatan, ikut serta berperan aktif dalam suatu aktifitas tertentu. ${ }^{9}$

Berdasarkan teori-teori di atas dapat diketahui bahwa minat mengandung beberapa unsur diantaranya:

1) Kecendrungan

\footnotetext{
${ }^{8}$ Syaiful Bahri Djamarah, Psikologi Belajar, (Jakarta: , 2008), hlm. 75

${ }^{9}$ Dewa Ketut Sukardi, Bimbingan dan Konseling, (Jakarta: Bina Aksara, 2005), hlm. 63
} 
Kecendrungan merupakan hasrat agar kita betul-betul melakukan sesuatu perbuatan atau aktifitas tertentu. Kecendrungan biasanya dipengaruhi oleh komponen kognitif atau pengetahuan dan komponen efektif atau emosional.

2) Kemauan

Kemauan adalah dorongan dari yang berdasarkan pikiran atau perasaan serta seluruh pribadi seseorang dapat membuat kegiatan terarah pada tujuan tertentu yang berhubungan dengan kebutuhan hidup pribadi. ${ }^{10}$

3) Kehendak

Kehendak merupakan salah satu unsur pendorong agar berbuat sesuatu dan merupakan motor pergerak perbuatan dan kelakuan manusia.

Agar proses penyaluran zakat mal dapat berjalan dengan baik, maka seseorang harus membutuhkan minat dalam penyaluranan zakat mal, karena apabila seseorang telah berminat dalam menyalurkan zakat mal secara otomatis proses penyaluran zakat malnya akan berjalan dengan baik dan hasilnya akan mencapai taraf yang optimal.

Usaha badan amil zakat untuk menarik perhatian masyarakat untuk mau menyalurkan zakat malnya ke badan amil zakat diantaranya:

1) Menghubungkan pentinganya zakat mal bagi kaum fakir

2) Usaha untuk membentuk minat masyarakat

3) Menggunakan minat masyarakat yang sudah ada untuk mendistribusikan zakat malnya ke badan amil zakat

\footnotetext{
${ }^{10}$ Abu Ahmadi, Psikologi Umum, (Jakarta: Rineka Cipta, 2009), hlm. 83
} 


\section{Peranan Minat}

Minat adalah kecendrungan yang tetap untuk memperhatikan dan mengenang beberapa kegiatan dengan penuh rasa suka dan senang, tanpa ada yang menyuruh,serta sadar bahwa kegiatan itu berkaitan erat dengan dirinya. Minat dipandang berperan dalam kegiatan bermasyarakat, karena minat mengandung berbagai peranan sebagai berikut:

1) Minat menentukan sukses atau gagalnya kegiatan seseorang

2) Minat yang besar akan mendorong motivasi dalam mengikuti kegiatan mendistribusikan zakat mal

3) Minat mendorong untuk berbuat lebih giat dan lebih baik

4) Minat merupakan salah satu faktor untuk meraih kesuksesan.

Namun terlepas dari masalah populer atau tidak, minat seperti yang di pahami dan dipakai oleh orang selama ini dapat mempengaruhi kualitas pencapaian. Kemudian, karena pemusatan perhatian yang intensif itulah yang memungkinkan masyarakat tadi untuk lebih giat lagi menyalurkan zakat malnya. Badan amil zakat dalam kaitan ini seyogyanya berusaha membangkitkan minat masyarakat untuk mau menyalurkan zakat malnya ke badan amil zakat.

Minat merupakan alat motivasi yang utama yang dapat membangkitkan kegairahan dalam rentangan waktu tertentu. Oleh karena itu, badan amil zakat perlu membangkitkan minat masyarakat agar pendistribusian zakat mal berjalan dengan lancar kepada yang membutuhkan. Ada beberapa macam cara yang dapat dilakukan badan amil zakat untuk membangkitkan minat masyarakat sebagai berikut:

1) Betapa pentingnya berbagi kepada sesama yang membutuhkan. 
2) Besarnya pahala bagi seseorang yang mau membagikan sebagian hartanya kepada orang yang membutuhkan.

3) Memberikan kepercayaan kepada masyarakat bahwa harta yang dititipkan ke badan amil zakat disalurkan dengan baik oleh badan amil zakat kepada yang membutuhkan.

4) Menggunakan berbagai macam bentuk dan teknik pendekatan kepada masyarakat supaya masyarakat tertarik untuk memakai jasa badan amil zakat dalam penyaluran zakat malnya.

\section{Cara Meningkatkan Minat Masyarakat}

Ada beberapa hal yang dapat mempengaruhi minat masyarakat untuk membayar zakat: ${ }^{11}$

1) Kepuasan, hal ini dapat memengaruhi masyarakat dalam membayar zakat. Masyarakat merasa puas ketika sudah mengeluarkan zakat karena menganggap bahwa berzakat adalah bentuk rasa syukur kepada Allah SWT dan merasa senang karena dapat membantu orang lain yang membutuhkan.

2) Keimanan, keimanan seseorang dapat mempengaruhi dalam membayar zakat. keimanan memiliki beberapa atribut yaitu shalat berja ma'ah di masjid, membaca buku-buku agama, shalat 5 waktu sehari semalam, dan menghadiri majelis ilmu atau pengajian.

3) Kecakapan organisasi pengelola zakat (OPZ), baik BAZNAS maupun LAZ. Kenyamanan masyarakat dalam berzakat melalui OPZ, dan pelayanan yang diberikan oleh OPZ kepada muzakki sebagai donator. Semakin bagus dan tepat sasaran program yang digulirkan oleh OPZ, maka kepercayaan mereka akan semakin besar. Selama ini masyarakat

${ }^{11} \mathrm{http}: / /$ www.depokpos.com/arsip/2017/07/minimnya-kesadaran-membayar-zakat (diambil Tgl: 16/03/2018) 
belum sepenuhnya berzakat via OPZ, karena belum maksimalnya sosialisasi yang dilakukan oleh OPZ, sehingga ma syarakat umum tidak mengetahui profesionalitas OPZ dalam menjalankan program.

4) Sosialisasi dan publikasi, sosialisasi langsung kepada masyarakat sangat memengaruhi kemauan mereka dalam berzakat.OPZ harus menggencarkan sosialisasi kepada masyarakat melalui metode yang lebih massif, tidak hanya memberikan pengumuman saja melainkan berkunjung langsung kepada masya rakat yang berpotensi mengeluarkan zakat. Selain itu, semua kegiatan pemasukan dan pendistribusian zakat harus dipublikasikan kepada masya rakat terutama muzakki sehingga kepercayaan masyarakat tumbuh dan mereka semakin bersemangat dalam mengeluarkan kewajiban zakat.

5) Balasan, tidak dapat dipungkiri bahwa masyarakat dalam mengeluarkan zakat juga mengharapkan balasan, walaupun balasan itu tidak dalam bentuk materi. Masyarakat mengharapkan bahwa dengan berzakat harta mereka menjadi bersih sesuai dengan tujuan zakat itu sendiri adalah dapat mensucikan harta mereka. Selain itu muzakki juga memiliki harapan bahwa dengan mereka berzakat dapat menjadi dorongan bagi yang lain untuk berzakat tanpa bermaksud ria.

6) Regulasi, regulasi adalah pemotongan gaji secara langsung dari tempat dimana orang tersebut bekerja. Kebijakan pemotongan zakat secara langsung dari gaji pokok Pegawai Negeri Sipil (PNS) menyebabkan meningkatnya penerimaan zakat.

Dengan demikian jelas bahwa regulasi atau kebijakan penarikan zakat secara langsung dari tempat mereka bekerja dianggap efektif. Masyarakat merasa tidak perlu repot lagi untuk menghitung dan menyalurkan zakat walaupun masih ada masyarakat yang mengeluh terhadap keterbukaan atau transparansi lembaga zakat yang mengelola harta 
Volume 1 No. 2

zakat, baik dalam proses pengumpulannya maupun dalam proses pendayagunaannya.

\section{Zakat Mal}

Kata zakat mempunyai dua pengertian etimologi (bahasa) dan terminologi (istilah). Zakat secara terminologi juga memiliki dua pengertian, mensucikan jiwa dengan keimanan dan mensucikan jiwa dengan memberika sebagian harta benda. Zakat dalam tinjauan etimologi berarti annama' (pertumbuhan) dan az-ziyadah (perkembangan). ${ }^{12}$

Zakat menurut UU No. 23 tahun 2011 tentang pengelolaan zakat adalah harta yang wajib dikeluarkan oleh seorang muslim atau badan usaha untuk dberikan kepada yang berhak menerimanya sesuai dengan syariat islam. ${ }^{13}$ Zakat menurut istilah fiqh adalah sejumlah harta tertentu yang harus diserahkan kepada oarang-orang yang berhak menurut syariat Allah SWT. ${ }^{14}$

Menurut para fuqaha Madzhab Hanafi, zakat mal ialah pemberian harta karena Allah, agar dimiliki oleh orang fakir yang beragama islam, selain Bani Hasim atau bekas budaknya, dengan ketentuan bahwa manfaat harta itu harus terputus, yakni tidak mengalir kepada pemiliknya yang asli dengan cara apapun.

Menurut Madzhab Maliki bahwa zakat mal ialah mengeluarkan bagian tertentu dari harta tertentu pula, yang telah mencapai nisab, diberikan kepada yang berhak menerimanya, yakni bila harta itu merupakan milik

\footnotetext{
${ }^{12}$ Syaikh Muhammad Bin Shalih Al-Utsaiman, Sifat Zakat Nabi SAW (Jakarta: Darus Sunnah, 2014), hlm. viii.

${ }^{13}$ Andri Soemitra, Bank dan Lembaga Keuangan Syariah, (Jakarta: Kencana, 2010), hlm. 408.

${ }^{14}$ Yusuf Qardawi, Hukum Zakat, (Bogor: Pustaka Litera AntarNusa, 2011), hlm. 34.
} 
penuh dari si pemberi dan telah berulang tahun, untuk selain barang tambang dan hasil pertanian.

Menurut Madzhab Syafi'i bahwa zakat mal ialah harta tertentu yang dikeluarkan dari harta tertentu dengan cara tertentu pula.

Menurut Madzhab Hambali bahwa zakat mal ialah hak yang wajib dikeluarkan dari suatu harta. ${ }^{15}$

Zakat wajib bagi muslim yang merdeka dan memiliki satu nisab dari harta apapun dari harta apapun yang wajib dizakati. Syarat nisab adalah: Pertama, harus melebihi kebutuhan primer yang dibutuhkan oleh seseorang. Kedua, harus terlalui haul hijrah. Dimana awal dianggapnya haul adalah sejak hari memiliki nisab tersebut dan harus benar-benar sempurna memiliki dalam semua haul. Andaikan kurang kepemilikannya ditengah-tengah haul dimulai sejak hari kesempurnaan itu. ${ }^{16}$

Pelaksanaan zakat itu merupakan salah satu usaha untuk:

1) Membersihkan jiwa muzaki wajib pajak dari pada sifat-sifat bakhil, tamak serta menanamkan perasaan cinta kasih (solidaritas)terhadap golong yang lemah.

2) Membersihkan harta yang kotor karena campur dengan harta mustahik (orang yang berhak menerima).

3) Menumbuh kembangkan kekayaan muzaki

4) Membersihkan jiwa para mustahik dari perasaan sakit (iri) hati, benci dan dendam terhadap golongan kaya yang hidup dalam serba kemewahan tetapi tidak sudi mengeluarkan zakat.

${ }^{15}$ Syauqi Ismail Sahhatih, Penerapan Zakat dalam Bisnis Modern, (Bandung: CV Pustaka Setia, 2007), hlm. 19-21. 34

${ }^{16}$ Sayyid Sabiq, Fiqih Sunnah Jilid 2, (Depok: Madina Adi Pustaka, 2014), hlm. 
5) Memberikan modal kerja kepada golongan lemah untuk menjadi manusia yang berkemampuan hidup layak. ${ }^{17}$

Islam mewajibkan zakat dalam harta emas, tanaman, buah-buahan dan benda dagangan, hewan ternak, barang tambang, serta harta timbunan. ${ }^{18}$

1) Emas

Jika sudah mencapai 93,6 gram dan berlalu haul-nya, maka kewajiban zakatnya adalah 2,5\% dari 93,6 gram.

2) Perdagangan

Barang siapa memiliki kadar nisab dari harta benda niaga yang berlalu haul-nya maka dia menaksirnya di akhir haul dan dia mengeluarkan zakatnya, yaitu 2,5\% nilainya. Begitulah yang dilakukan si pedagang dalam mengkalkulasikan semua harta niagadi setiap tahunnya. Haul tidak berlaku kecuali kadar harta yang dimilikinya itu sudah mencapai nisab.

3) Tanaman dan buahan

Zakat tanaman dan buah-buahan itu tidak wajib di zakati, kecuali sudah mencapai 5 wassaq setelah dibersihkan dari jerami dan kulitnya. Jika belum dibersihkan dan masih tertinggal kulinya, maka di isyaratkan untuk mencapai 10 wassaq. Kadar kewajiban mengeluarkan zakatnya berbeda-beda tergantung dengan pengairannya. Jika tanpa mengurangi alat irigasi maka wajib zakatnya 10\%, tapi apabila menggunakan alat irigasi maka wajib zakatnya 5\%

4) Perternakan

Barang siapa memiliki nishab unta, sapi, atau kambing kemudian melahirkan ditengah-tengah haul, maka wajib menzakati semuanya

${ }^{17}$ Pramono Sjechul Hadi, Sumber-sumber Penggalian Zakat, (Jakarta: Pustaka Firdaus, 1992), hlm. 34-35.

${ }^{18}$ Sayyid Sabiq, Op. Cit, hlm. 39 
ketika sempurna haul untuk hewan besar. Dia mengeluarkan zakat satu untuk induk dan ternaknya menurut pendapat mayoritas ahli ilmu.

5) Rikaz adalah pendaman jahiliah dan kewajibannya adalah seperlima. Adapun empat perlima sisanya adalah untuk pemilik awal tanah jika memang terdeteksi. Dan jika meninggal, maka untuk ahli waris jika memang terdeteksi, bila tidak maka diatrus ke baitul mal.

\section{Zakat Mal Memiliki Tiga Segi, yaitu:}

1) Segi Ibadah: pada sisi ini disyaratkan niat menurut sebagian para ulama, dan amal bertujuan untuk melaksanakan perintah Allah SWT.

2) Segi Sosial: ketika masyarakat dari sebagian keluarga, terutama mereka fakir miskin yang mempunyai hak zakat tersebut.mereka membutuhkan bantuan dari masyarakat lainya yang bercukupan. Begitu juga mereka yang mempunyai banyak hutang, para budak dan ibnu sabil.

3) Segi Ekonomi: segi ekonomi adalah sis ketiga yang merupakan sisi pelengkap dari zakat. Walaupun masalah ekonomi merupakan pembahasan yang sudah sering dilakukan dalam usaha mengembangkan keuangan, tetapi kajian ekonomi zakat sangat jarang dilakukan. ${ }^{19}$

Tujuan, fungsi dan hikmah zakat sangatlah banyak dalam menata kehidupan sosial baik terhadap sikap dan kepentingan masyarakat. Diantaranya fungsi dan manfaat zakat adalah:

1) Menolong orang yang lemah dan susah agar dapat menunaikan kewajiban terhadap Allah dan sesama makhluk.

${ }^{19}$ Abdul Alhamdi Mahmud Al-Baily, Ekonomi Zakat Sebuah Kajian Moneter dan Keuangan Syariah, (Jakarta: PT Raja Grafindo Persada, 2006), hlm. 3-4 
2) Diri dari sifat kikir dan akhlak tercela serta mendidik diri agar bersifat mulia dan pemurah dengan membinasakan membayar amanah.

3) Sebagai ucapan syukur dan terima kasih atas nikmat yang diberikan kepadanya

4) Mendekatkan hubungan kasih dan mencintai antara si kaya dengan si miskin.

5) Menjaga kejahatan-kejahatan yang akan timbul dari si miskin dan orang telantar.

6) Menghilangkan sifat kikir.

7) Membersihkan sifat kikir.

8) Mengembangkan rasa tanggung jawab sosial.

9) Mendidik manusia untuk disiplin dalam menunaikan kewajiban dan menyerahkan hak orang lain.

10) Sarana pemerataan rezeki guna keadilan sosial.

11) Membersihkan jiwa muzaki.

12) Membersihkan harta muzaki.

13) Fungsi sosial ekonomi.

14) Fungsi ibadah

\section{Kesimpulan}

Berdasarkan hasil yang disebarkan, diperoleh persentase $28,72 \%$, ini artinya Masyarakat Perumahan Nusa Indah Permai Tembilahan Barat "Kurang Berminat" dalam Menyalurkan Zakat Mal Ke Badan Amil Zakat Nasional Kabupaten Indragiri Hilir. Berdasarkan hasil data tersebut peneliti melakukan suatu upaya untuk mengatasi rendahnya minat masyarakat dengan menyampaikan ke Badan Amil Zakat Kabupaten Indragiri Hilir supaya memberikan pemahaman kepada masyarakat di Perumahanan Nusa 
Indah tentang tugas Badan Amil Zakat sebagai tempat penerima dan penyaluran zakat yang tepat.

Menurut peneliti untuk meningkatkan minat masyarakat dalam menyalurkan zakat mal ke badan amil zakat nasional Kabupaten Indragiri Hilir yaitu diharapkan Kepada kepala Badan Amil Zakat Nasional Kabupaten Indragiri Hilir diharapkan agar memberikan sosialisasi kepada masyarakat tentang Lembaga Badan Amil Zakat Nasional sebagai wadah penerima dan penyalur zakat mal masyarakat supaya masyarakat tidak menyalurkan zakat malnya secara pribadi dan Kepada masyarakat diharapkan agar menyalurkan zakat malnya apabila sudah sampai haul dan nisabnya ke Badan Amil Zakat Nasional karena Badan Amil Zakat Nasional adalah lembaga penerima dan penyalur zakat yang sudah dibentuk pemerintah.

\section{Referensi}

Abdul Alhamdi Mahmud Al-Baily, Ekonomi Zakat Sebuah Kajian Moneter dan Keuangan Syariah, (Jakarta: PT Raja Grafindo Persada, 2006)

Abu Ahmadi, Psikologi Umum, (Jakarta: Rineka Cipta, 2009)

Andi Mapare, Psikologi Remaja, (Surabaya: Usaha Nasional, 2003)

Andri Soemitra, Bank dan Lembaga Keuangan Syariah, (Jakarta: Kencana, 2010)

Dewa Ketut Sukardi, Bimbingan dan Konseling, (Jakarta: Bina Aksara, 2005)

H. Djaali, Psikologi Pendidikan, (Jakarta: Bumi Aksara, 2009)

Muhammad Abu Zahra, Zakat dalam Persfektif Sosial, (Jakarta: Pustaka Firdaus, 2004) 
Volume 1 No. 2

Ngalim Purwanto, Psikologi Pendidikan, (Bandung: PT Remaja Rosdakarya, 2014)

Pramono Sjechul Hadi, Sumber-sumber Penggalian Zakat, (Jakarta: Pustaka Firdaus, 1992)

Riduwan, Belajar Mudah Penelitian Untuk Guru-Karyawan dan Peneliti Pemula, (Bandung: ALFABETA, 2012)

Sayyid Sabiq, Fiqih Sunnah Jilid 2, (Depok: Madina Adi Pustaka, 2014)

Slameto, Belajar dan Faktor- faktor Yang Mempengaruhi, (Jakarta: Rineka Cipta, 2010)

Suharsismi Arikunto, Prosedur Penelitian Suatu Pendekatan Praktik, (Jakarta: Rineka Cipta, 2006)

Sugiyono, Metode Penelitian Pendidikan, Pendekatan Kuantitatif, Kualitatif, dan R\&D, (Bandung: Alfabeta, 2011)

Syaiful Bahri Djamarah, Psikologi Belajar, (Jakarta: , 2008)

Syaikh Muhammad Bin Shalih Al-Utsaiman, Sifat Zakat Nabi SAW (Jakarta: Darus Sunnah, 2014), hlm. viii

Yusuf Qardawi, Hukum Zakat, (Bogor: Pustaka Litera AntarNusa, 2011)

Yusuf Wibison, Mengelola Zakat Indonesia Diskursus Pengelolaan Zakat Nasional dari Rezim Undang-undang Nomor 38 Tahun $1999 \mathrm{Ke}$ Rezim Undang-undang Nomor 23 Tahun 2011, (Jakarta: Kencana, 2015)

Yusuf Zainal Abidin dan Beni Ahmad Saebani, Pengantar Sosial Budaya di Indonesia, (Bandung: CV Pustaka Setia, 2014)

http://syariahcooperation.blogspot.co.id/2011/03/badan-amil-zakat.html (diambil Tgl: 16/03/2018)

http://www.depokpos.com/arsip/2017/07/minimnya-kesadaran-membayarzakat (diambil Tgl: 16/03/2018) 